\title{
Jakarta's Tourism Competitiveness: An Environmental Perspective
}

\author{
$1^{\text {st }}$ Yunita Ismail \\ Environment Engineering \\ Study Program \\ President University \\ Cikarang, Indonesia \\ yunitaismail@president.ac.id
}

\author{
$2^{\text {nd }}$ Filda Rahmiati \\ Management Study Program \\ President University \\ Cikarang, Indonesia \\ Universiti Teknikal Malaysia \\ Melaka
}

Melaka, Malaysia

filda.rahmiati@president.ac.id

\author{
$5^{\text {th }}$ Dwi Larso \\ School of Business and \\ Management \\ Bandung Institute of Technology \\ Bandung, Indonesia \\ dwilarso@sbm-itb.ac.id line 1:
}

\author{
$3^{\text {rd }}$ Grace Amin \\ Management Study Program \\ President University \\ Cikarang, Indonesia \\ grace_amin@president.ac.id
}

\author{
$4^{\text {th }}$ Togar Simatupang \\ School of Business and \\ Management \\ Bandung Institute of Technology \\ Bandung, Indonesia \\ togar@sbm-itb.ac.id
}

\author{
$6^{\text {th }}$ Norfaridatul Akmaliah Othman \\ Faculty of Technology \\ Management and \\ Technopreneurship \\ Universiti Teknikal Malaysia \\ Melaka \\ Melaka, Malaysia \\ norfaridatul@utem.edu.my
}

\begin{abstract}
The competitiveness of tourism destinations is important to have, so they can maintain tourism sustainability that provides economic, social and environmental benefits. Environmental problems that arise in the implementation of tourism activities make the environmental dimension as one of crucial the dimensions of competitiveness. Jakarta as a tourist destination visited by many tourists must pay attention to the competitiveness of its environment. The results of the correlation calculation between the amounts of waste generation with the number of visitors at 14 tourist destinations in Jakarta show a close relationship between the two. Tourism development must fulfill sustainable development, considering that tourism is an industry that must protect nature or the environment in order to be able to provide tourism services.
\end{abstract}

Keywords-destination environmental competitiveness, solid waste volume, visitor, sustainability tourism

\section{INTRODUCTION}

All tourist destinations need to improve their competitive abilities. This is due to the increasing number of tourist destinations that are developing and increasingly in demand by foreign tourists. It is crucial for any party involved in the tourist industry, especially the government and business people, to know the competitive position of the tourist area.

The tourism sector contributes significantly to the country's economy (Table 1). It can be seen that the role of the tourism sector has increased from 2015 to 2016 for all roles.

\begin{tabular}{|c|c|c|c|c|c|c|}
\hline Description & $\begin{array}{c}\text { National } \\
\text { Economic } \\
\text { Value } 2015\end{array}$ & $\begin{array}{c}\text { National } \\
\text { Economic } \\
\text { Value } 2016\end{array}$ & $\begin{array}{l}\text { The } \\
\text { Economic } \\
\text { Value of } \\
\text { Tourism } \\
2015\end{array}$ & $\begin{array}{l}\text { The } \\
\text { Economic } \\
\text { Value of } \\
\text { Tourism } \\
2016\end{array}$ & $\begin{array}{l}\text { The Role } \\
\text { of The } \\
\text { Tourism } \\
\text { Sector } \\
2015(\%)\end{array}$ & $\begin{array}{l}\text { The Role } \\
\text { of The } \\
\text { Tourism } \\
\text { Sector } \\
2016(\%)\end{array}$ \\
\hline Output & $22,238,560$ & $24,022,904$ & $1,244,054$ & $1,415,072$ & 5.57 & 5.89 \\
\hline GDP & $11,531,100$ & $12,406,774$ & 630,986 & 722,597 & 5.47 & 5.82 \\
\hline $\begin{array}{l}\text { Labor } \\
\text { ompensation }\end{array}$ & $3,709,100$ & $3,990,555$ & 187,967 & 214,474 & 5.07 & 5.37 \\
\hline $\begin{array}{l}\text { Tax on Net } \\
\text { roduction }\end{array}$ & 96,760 & 104,102 & 5,832 & 6,683 & 6.03 & 6.42 \\
\hline $\begin{array}{l}\text { Job } \\
\text { eation } \\
\text { pportunities }\end{array}$ & $114,819,199$ & $118,411,973$ & $4,276,872$ & $4,962,871$ & 3.72 & 4.19 \\
\hline
\end{tabular}

From Table 1, it shows that the role of the tourism sector was improving, both in employment opportunities and in contributing to GDP. However behind the good contribution from the economic side, the tourism sector has an impact on the environment. The beauty of attractions can be threatened by the increasing number of visitors. A good contribution to economic growth can be a boomerang on environmental quality. Bali as a major tourist destination in Indonesia is now experiencing a water crisis, groundwater is drying up, and 100 tons of garbage is transported to landfills every day (http://beritagar.id).

From previous study [1], it was found that the influence of tourism activities on $\mathrm{CO} 2$ emissions in the western and eastern European Union regions was different. In addition the environmental impacts such as garbage, water crisis, air pollution, tourism will also have an impact on the destruction of the tourist attraction by the excessive occurrence of tourists. The number of tourists visiting exceeds the carrying capacity 
that can be provided by the tourist destination. Over tourism has now become a problem, locals are already disturbed and natural resources are being rapidly drained. Some authors have specifically referred to environmental sustainability as a key variable for the competitiveness of tourist destination [2]; [3].

Therefore, the tours offered must consider environmental sustainability, so the tourism industry can be sustainable. The sustainability of a tourist destination can be built by increasing the competitiveness of the tourist destination. The competitiveness of a tourist destination can be seen by using several dimensions, such as the economic dimension, the political dimension, the sociocultural dimension, the technological dimension, and the environmental dimension [4]. Economic, geographical, cultural and political features are significant determinants of the competitiveness of tourist destinations [5].

The economic dimension is a dimension that was always used to see the competitiveness of a tourist destination. The economic dimension consists of 4 attributes commonly referred to as 'Porter diamond' (Porter, 1996 in [4]). First are the factor conditions, which are conditions of providing production factors such as labor, infrastructure, to provide tourism products. Second are the demand conditions, or the market demand behavior towards tourism products. Third is supporting industrial conditions, the existence of supporting tourism industries and fourth is the availability of firm strategy, structure and rivalry, how businesses are made, organized and managed including conditions of domestic competition.

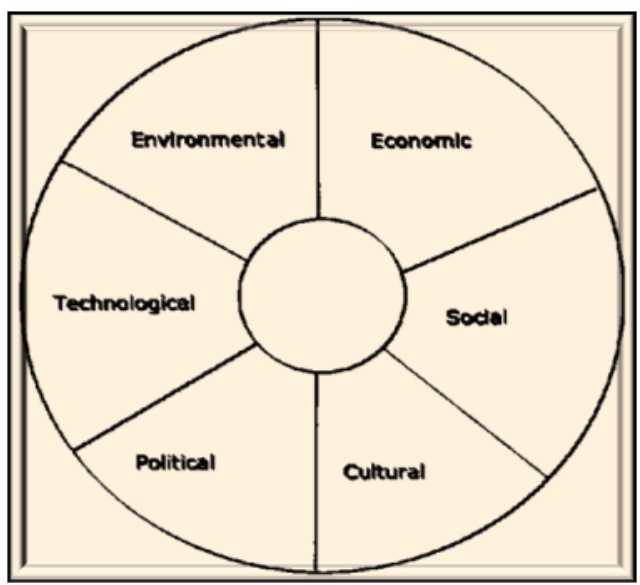

Fig. 1. The multidimensional strengths of tourism destination [4]

The next dimension is the political dimension. Political conditions in tourist destinations will provide a sense of security for tourists and will make tourists able to enjoy the offered tours. Political competitiveness will provide individual welfare and public welfare.

The sociocultural dimension is a socio-cultural condition of the community that can make tourists come to visit the place. This socio-cultural experience is an experience that cannot be provided by other places, because of its uniqueness. This sociocultural dimension can be the strongest attractor to bring tourists.

The technological dimension lately has become one of the dimensions of the competitiveness of tourist destinations. With the expansion of online facilities that can be obtained by tourists, an area is increasingly well known. Finally is the environmental dimension. The environmental dimension is increasingly seen as important due to environmental damage due to this tourism activity. The awareness of tourists to protect the environment is also a trigger which is higher both morally and practically.

One tourist destination that is also visited by many foreign tourists is Jakarta. Jakarta as the capital of the country is not only visited by tourists for vacation, but many destinations in the city are also visited by business people or workers. As one of the tourist destinations, Jakarta is supported by capital facilities, such as transportation facilities, security facilities, cleaning facilities and many others.

The purpose of this paper is to identify Jakarta's environmental competitiveness as a tourist destination. The competitiveness dimension seen is the environmental dimension, because it is realized that the environmental impact of tourism activities is increasingly worrying. The environmental condition saw the amount of solid waste from tourism destination in Jakarta and its correlation with the number of visitor.

\section{METHOD}

This research intentionally chose Jakarta as a tourist destination for its sample. The approach used is quantitative using secondary data. The data collected is the amount of waste generated and the number of visitors from 14 tourist sites in Jakarta. In addition, data were also collected through interviews with the government through the Department of Tourism and Culture of the Provincial Government of DKI Jakarta Province and the private sector, the Management Agency of Taman Mini Indonesia Indah.

The data obtained were processed using Pearson correlation coefficient to see the correlation between the number of visitors and the generated waste and also the correlation between the areas of tourist sites with the amount generated waste.

\section{RESULTS AND DISCUSSION}

Environmental considerations in the tourism industry are increasingly becoming important, especially after the destruction of the environment at the cost of tourist destination. Sustainable tourism may be regarded most basically as the application of the sustainable development idea to the tourism sector. Sustainable tourism is the tourism development that meets the needs of the present without compromising the ability of future generations to meet their own needs [6].

\section{A. Solid Waste}

From 14 tourist destinations in Jakarta, data were obtained from waste generated every day. Table 2 presents data on the number of visitors, area and volume of waste generated every day [7]. 
TABLE II. SOLID WASTE FROM 14 TOURIST DESTINATION AT JAKARTA

\begin{tabular}{|c|c|c|c|c|}
\hline No & Tourism Destination & $\begin{array}{l}\text { Number } \\
\text { of Visitor }\end{array}$ & $\begin{array}{l}\text { Area } \\
(\text { Ha) }\end{array}$ & $\begin{array}{c}\text { Solid Waste } \\
\text { Volume } \\
\text { (m3/day) }\end{array}$ \\
\hline 1 & Taman Impian Jaya Ancol & $16,085,604$ & 552.00 & 66.38 \\
\hline 2 & $\begin{array}{l}\text { Taman Mini Indonesia } \\
\text { Indah }\end{array}$ & $4,587,735$ & 250.00 & 7.47 \\
\hline 3 & $\begin{array}{l}\text { Taman Margasatwa } \\
\text { Ragunan }\end{array}$ & $4,100,570$ & 140.00 & 12.64 \\
\hline 4 & Monumen Nasional & $1,156,208$ & 80.00 & 1.96 \\
\hline 5 & Museum Nasional & 245,848 & 26.34 & 1.00 \\
\hline 6 & $\begin{array}{l}\text { Museum Abri Satria } \\
\text { Mandala }\end{array}$ & 38,756 & 5.00 & 0.61 \\
\hline 7 & Museum Sejarah Jakarta & 196,443 & 13.59 & 0.20 \\
\hline 8 & Museum Tekstil & 50,779 & 1.60 & 0.50 \\
\hline 9 & Museum Bahari & 26,152 & 9.80 & 0.68 \\
\hline 10 & $\begin{array}{l}\text { Museum Seni Rupa dan } \\
\text { Keramik }\end{array}$ & 60,765 & 8.30 & 0.48 \\
\hline 11 & Museum Wayang & 221,718 & 0.63 & 0.40 \\
\hline 12 & Gedong Joang 45 & 23,410 & 3.66 & 0.20 \\
\hline 13 & $\begin{array}{l}\text { Taman Arkeologi Onrust } \\
\text { (Kep Seribu) }\end{array}$ & 13,954 & 12.00 & 0.00 \\
\hline 14 & Pelabuhan Sunda Kelapa & 40,210 & 760.00 & 3.36 \\
\hline
\end{tabular}

Source: BPLHD Jakarta, 2016

From Table 2, it can be seen that Taman Impian Jaya Ancol and Ragunan Wildlife Park are the two tourist destinations that produce the most waste per day. However, the data above is valid in 2015, while the data for the latest conditions have not been obtained. For example, for garbage produced from Taman Mini Indonesia Indah, from interviews with the environmental section of the TMII Management Agency, it was found that the waste from TMII reached an average of 6 tons $\left(=6 \mathrm{~m}^{3}\right)$ every day.

The results of the calculation of the correlation between the number of visitors and waste generation at the tourist destination are shown in Table 3.

TABLE III. CORRELATION BETWEEN THE NUMBER OF VISITOR AND SOLID WASTE VOLUME ( $\mathrm{m}^{3} /$ day)

\begin{tabular}{|c|c|c|c|}
\hline & & V & SW \\
\hline \multirow{4}{*}{ V } & Pearson Correlation & 1 & $.982^{* *}$ \\
\hline & Sig. (2-tailed) & & .000 \\
\hline & $\mathrm{N}$ & 14 & 14 \\
\hline & Pearson Correlation & $.982^{* *}$ & 1 \\
\hline \multirow[t]{2}{*}{ SW } & Sig. (2-tailed) & .000 & \\
\hline & $\mathrm{N}$ & 14 & 14 \\
\hline
\end{tabular}

From Table 3 it can be seen that the number of visitors and the amount of waste generated has a very close correlation $(\mathrm{r}=$ 0.982 ) and is significant at the 0.01 significance level. It can be seen that each visitor leaves rubbish at the tourist site while enjoying the tour. Not all visitors throw their garbage in the trash bin. From the results of interviews with TMII managers, it was found that TMII has a cleaning fleet that must sweep all areas of the park every day, so garbage is collected and then transported to the collection site. For other tourist destinations in Jakarta, the cleanliness of the park is maintained by the DKI Jakarta Provincial Sanitation Office.

According to [8], there is a positive correlation between environmental knowledge and environmental attitude. There is a positive correlation between environmental attitude and environmental behavior and a positive correlation between environmental knowledge and environmental behavior.

The responsibility to protect the environment must be borne by the visitors, so protecting the environment will be performed even if they are traveling. Awakening environmental behavior is determined by the triggers that determine a particular tourist site. Based on triggers in a place, environmental behavior will develop well [9].

However, tour operators are responsible for providing excellent tourism services, perceived service quality provided by tour operators has a positive impact on environmentally committed and environmentally responsible behavior [10].

The relationship between the number of visitors and the area of tourism is not too close $(\mathrm{r}=0.564)$ (Table 4). At the tourist sites there are certain locations considered as favorite locations and many visitors are gathered in the area. For managers of tourist destinations this can be a consideration in the placement of trash bins.

TABLE IV. CORRELATION SOLID WASTE VOLUME ( $\mathrm{m}^{3} /$ day) AND AREA OF TOURIST DESTINATION

\begin{tabular}{|c|c|c|c|}
\hline & & SW & A \\
\hline \multirow{4}{*}{ SW } & Pearson Correlation & 1 & $.564^{*}$ \\
\hline & Sig. (2-tailed) & & .036 \\
\hline & & 14 & 14 \\
\hline & Pearson Correlation & $.564^{*}$ & 1 \\
\hline \multirow[t]{2}{*}{ A } & Sig. (2-tailed) & .036 & \\
\hline & $\mathrm{N}$ & 14 & 14 \\
\hline
\end{tabular}

\section{B. Jakarta's Environmental Competitiveness}

In seeing Jakarta's competitiveness as a tourist destination, the availability of data is very limited. City facilities will also serve the needs of supporting facilities for tourist destinations, so Jakarta's competitiveness as a tourist destination will be largely determined by Jakarta as the country's capital.

As a tourist destination, Jakarta must maintain the sustainability of its tourist destinations. Sustainable tourism is the direction of tourism development, so the competitiveness of tourist destinations can be increased, and vice versa [11].

With the development of an environmentally friendly tourism industry, tourism will provide an important role in accelerating the country's economic growth [1]. The influence of the tourism industry on $\mathrm{CO}_{2}$ emissions is determined by the 
adoption of an environmentally friendly tourism industry development. Long-term relationship between economic growths $\mathrm{CO}_{2}$ emissions were not significant [12]. In addition, [13] found that economic benefit and ecological quality had the greatest effect on the coupling relationship system between tourism and environment.

\section{CONCLUSION}

1. The environmental competitiveness of Jakarta as a tourist destination cannot be separated from Jakarta as the nation's capital.

2. There is a close relationship between solid waste volume and the number of visitors to tourist attractions in Jakarta. This can be due to the lack of environmental behavior of the visitors.

3. The development of the tourism industry must consider the environment so that its sustainability is maintained.

\section{ACKNOWLEDGMENT}

The authors extend their gratitude to The Ministry of Research and Higher Education of Republic of Indonesia, for provided funding support in conducting this research on tourism in Jakarta.

\section{REFERENCES}

[1] Paramati, SR, M Shahbaz and Md Samsul A. Does tourism degrade environmental quality? A comparative study of Eastern and Western European Union. Transportation Research Part D. Elsevier. http://dx.doi.org/10.1016/j.trd.2016.10.034. 2016

[2] Hu, W., Wall, G., 2005. Environmental management. Environmental image and the competitive tourist attraction. Journal of Sustainable Tourism 13(6), 617-635.

[3] Huybers, T., Bennett, J., 2003. Environmental management and the competitiveness of naturebased tourism destinations. Environmental and Resource Economics 24, 213-233.

[4] Ritchie, JRB and G. I Crouch. The Competitive Destination. A Sustainable Tourism Perspective. CABI Publishing. London. 2003.

[5] Vega, MG and Andres JPT. Ranking world tourist destinations with a composite indicator of competitiveness: To weigh or not to weigh?. Journal of Tourism Management. 72. 281-291. Elsevier. 2019.

[6] Weaver, D. Sustainable tourism: Theory and practice. Elsevier. Singapore. 2006.

[7] BPLHD Jakarta. Laporan Status lingkungan hidup daerah Provinsi Daerah Khusus Ibukota Jakarta. PemProv DKI Jakarta. Jakarta. 2016.

[8] Zheng QJ, Xu AX, Kong DY, Deng HP and Lin QQ. Correlation between the environmental knowledge, environmental attitude

[9] Juvan E and Sara D. Drivers of pro-environmental tourist behaviors are not universal. Journal of Cleaner Production. Doi: 10.1016/j.jclepro.2017.08.087.

[10] He, X., Dongbin H, Scott RS, Lujun S, and Xiaohong C. Destination perceptions, relationship quality, and tourist environmentally responsible behavior. Tourism Management Perspective. 28. 93-1-4 2018.

[11] Fernadez,JIP., Pablo Juan CG and Juan Antonio EP. Does environmental sustainability contribute to tourism growth? An anlysis at the country level. Journal of Cleaner Production. Doi:10.1016/j.jclepro.2018.12.151

[12] Danish and Zhaohua W. Dynamic relationship between tourism, economic growth, and environmental quality. Journal of Sustainable Tourism. http://doi.org/1001080/09669582.2018.1526293. 2019.

[13] Tang, Zi. An integrated approach to evaluating the coupling coordination between tourism and the environment. Jounal of Tourism Management. 46. 11-19. Elsevier. 2015. 